\title{
Socioeconomic Status and Fertility Decline in Burkina Faso, 2003-2015
}

\author{
Dalomi Bahan ${ }^{1} \&$ Latif Dramani ${ }^{1}$
}

${ }^{1}$ Université de Thiès, Senegal

Correspondence: Latif Dramani, Université de Thiès, Senegal.

Received: December 12, 2018

Accepted: January 10, $2019 \quad$ Available online: February 12, 2019

doi:10.11114/aef.v6i2.3871

URL: https://doi.org/10.11114/aef.v6i2.3871

\begin{abstract}
The paper proposes to clarify whether fertility decline in Burkina Faso between 2003 and 2015 is explained by the differential distributions (composition effect and response effect) with focus on socioeconomic status (women's education, women's occupation and poverty). Using data from 2003 demographic and health survey (DHS) and 2015 demographic and health module of the Multisectoral Continuous Survey, we applied an extension of Blinder-Oaxaca decomposition approach to quantify the percentage of fertility decline attributable to distribution of the socio-economic status (composition effect) and the percentage attributable to women's fertility behavior (response effect) attributable to socio-economic status. We find the fertility decline is mainly explain to changes in the distribution of women according the different factors. Indeed, the composition effect represents $88 \%$ and only $12 \%$ for the response effect. Moreover, composition effect for socio-economic factors is estimated to $85.13 \%$ and the response effect is estimated to $34.23 \%$. These results suggest (i) to encourage girl's education by enrolling them in school but particularly by ensuring that they go at least to secondary school; (ii) create a minimum package of services for the promotion of modern methods of contraception, particularly for women working in agriculture and trade sector as well as those from poor households and living in rural areas; (iii) promote domestic work to allow more women to be interested.
\end{abstract}

Keywords: fertility decline, Blinder-Oaxaca decomposition, Burkina Faso

\section{Introduction}

It is well known that demographic transition is slow in sub-Saharan Africa (SSA). This slowness is mainly due to the high fertility observed in this part of the world (Bongaarts and Casterline, 2013). According to the results of 2015 Revision of World Population Prospects (UN), the total fertility rate in sub-Saharan Africa is estimated to 5 children per woman and varies across countries between 2 and 7 children per woman. One of the relevant questions examined in the research is what explains the high fertility in this part of the world where poverty levels are among the highest in the world. The literature on the determinants of fertility shows that these determinants are divided into two groups: the first group called proximate determinants includes biological factors (marriage, contraception, abortion and postpartum infertility) and the second includes socioeconomic and environment factors (Kingsley Davis and Blake, 1956; Bongaarts, 1978; 1982; 2015). The second group of factors influence fertility through the first one. Today, there is a consensus on the proximate determinants, but the measure of the effect undergoes revisions (Bongaarts, 1982; 2015). Socioeconomic and environment determinants depend to the context. In the conceptual model, socioeconomic factors include income, education, occupation, poverty etc. Based on the conceptual model proposed by Kingsley and Blake in 1956 that have been revised by Bongaarts $(1978,1982,2015)$, many theories have been developed to better explain the fertility levels.

In Burkina Faso some studies have analyzed the determinants of fertility based on the cross-sectional data (Guilella; 2000; Dakuyo and al., 2010; Zan, 2016). Guiella (2000) discusses the main features of the socio-economic organization that underlie Mossi production and reproduction. It appears that the resulting constraints, for both men and women, determine survival strategies where high fertility still plays a key role. Addressing the challenges of population growth, Dakuyo et al. (2010) argue that, with the demographic transition already under way in Burkina Faso, policies need to focus on the development of the educational and agricultural sectors that will lead to progress and genuine emancipation. Based on 1998 and 2010 DHS, Zan (2016) shows that family planning policies have had important effects on contraceptive knowledge and practice. However, the impact of modern contraceptive practice on fertility decline remains quite limited, showing the importance of other development policies in fertility decline. None of these studies address the contribution of socioeconomic status to fertility decline in Burkina Faso in a detailed way. Even if Zan 
(2016) seems to approach the issue by analyzing the contribution of population policies to fertility decline, he has remained at the descriptive level (bivariate analysis) with a focus on education. In addition, it indicates the importance of other development policies in the decline of fertility but without details on what it calls other development policies.

On the other side, several actions have been undertaken to improve economic growth, reduce poverty and improve the living conditions of the population: (i) implementing of Strategic Framework for Poverty Reduction 2000-2009; (ii) Accelerated Growth Strategy and Sustainable Development 2010-2015. Two population policies have been implemented: the first of which covered the period 1991-2009 and the second of which is implementing since 2010 . Moreover, the latest development plan which have the capture of the dividend demographic as one of its strategic goals set the target of 4.7 children per woman in terms of total fertility rate to achieve by 2020 . Despite these actions, poverty remains high: it increases from 44.5\% from 1994 to $46.7 \%$ in 2009 and decreased to $40.1 \%$ in 2015 (INSD, 1994; 2003; 2015). Total fertility rate declined from 6.0 in 2003 to 5.4 in 2015 with high variations between urban and rural area and also women's characteristics (INSD, 2003; 2010; 2015). Clarifying the determinants of fertility is important but indicates the sources of observed changes (a "composition effect") or effects (a "response effect") of fertility may help to inform country specific interventions for mitigating them particularly in the context of demographic dividend.

The main contribution of this paper is to clarify whether fertility decline is explained by the differential distributions (a "composition effect") or effects (a "response effect") with focus on socioeconomic status (women's occupation; women's education; poverty). The study also provides information on the dynamics of fertility over the past decade and with the most recent national data. The databases of these surveys have been linked using a time variable to identify the sources of changes in the fertility decline observed between 2003 and 2015. The choice of the period is justified by the availability of databases surveys respecting the geographic division currently in force, but this is also the period when we observed the largest fertility decline.

The paper is organized as follows. Following introduction, Section 2 presents the literature review on the link between socioeconomic status and fertility. Third section explains methodological approaches and the fourth section presents results and interpretations. The last section is devoted to discussions and conclusions. This section also provides suggestions in order to address the questions of fertility on the perspective to harness demographic dividend.

\section{Literature Review}

In this study, socioeconomic status is operationalized by three variables (women's occupation; women's education; poverty). An analysis of recent literature regarding the linkage between these variables and fertility are ambiguous particularly for poverty and women's occupation.

The literature also reveals the role of poverty in the explanation of fertility. The findings from existing research on the relationship between poverty and fertility in developing countries indicate that this relationship is diverse (Schoumaker and Tabutin, 1999). Some studies find the relationship to be positive, others show a weak relationship and in many developing countries, the link between poverty and fertility is negative. For other authors, there is an inverse J-shaped between poverty and fertility (Aassve and Woldegebrie, 2006). According to Easterlin (1969, 1973a, 1980), if the standard living of household is not better than what people knew during their adolescence, fertility can probably decline. The negative relationship is attributed to a number of reasons: (i) high fertility is considered a rational response to poverty (Becker and Lewis, 1973), so that, the benefits of having children outweigh their costs, leading to high demand for children, hence high fertility (Odwe, 2015); (ii) high infant mortality rate which tends to be stronger in poor households (Lutz, 1987). However, it is important to note that some authors have found positive relationships between poverty and fertility, whereas according to others, there is no significant relationship between these variables (Ainsworth, 1989). Applying a difference-in-difference strategy comparing the probability of having a new child among eligible and ineligible mothers both before and after the program inception, Garganta and al. (2016) find a significant and positive impact of cash transfers per child to households without workers in the formal sector on fertility in those households with at least one child, but no significant effect on childless households. Using Bongaarts' proximate determinants of fertility framework for 21 countries, Finlay and al. (2018) find that those in the richest wealth quintiles have had a more rapid decline in fertility rates than those in the poorest wealth quintiles.

Education is a strong predictor of the general level of fertility in developing countries because it contributes to improve an individual's knowledge and ability to process information regarding, fertility options and healthy pregnancy behaviors (Bongaarts, 2003; Doliger, 2004). Indeed, education raises a woman's permanent income through earnings, tilting her optimal fertility choices toward fewer offspring of higher quality (Becker, 1960). Under positive assortative mating, woman's education is causally connected to her mate's education (Behrman and al.; 2002), so that the effect of education on household permanent income is augmented through a multiplier effect. Schooling also reduced women's ideal family size and very high desired fertility (Behrman, 2015). For Matovu and al. (2017), having primary education were positively associated with fertility desire. Globally, women's education may have different effects on fertility through various mechanisms: (i) the relatively higher incomes and thus higher income forgone due to childbearing leads 
them to want fewer children (Lavy and al., 2011). The better care these women give increases their children's human capital and reduces the economic need for more children (Currie, 2003). The positive health impacts of education on both women and their children, means women are better able to give birth and children's higher survival rate reduces the desire for more (Kim, 2016); (ii) better knowledge of life and more opportunities in the adoption of contraceptives (Kim, 2010; Chicoine, 2012); and (iii) higher-educated women delay marriage or cohabitation, due to schooling and also opportunities in the labor market (Appleton, 1996).

The economic theory based on the consumption considers the demand for children depends on the mother's occupation but also the way of time allocation in the household (Becker, 1965). The recent investigation of the impact of mother's occupation on fertility show that the relationship between women's occupation and fertility is mixed (Schockaert, 2005). The 1987 United Nations study, based on global fertility surveys conducted in the 1970s, estimates the effect of female employment type on fertility. The results differ greatly from one country to another. However, modern and mixed-type jobs still have a more negative effect on fertility and stronger than other types of work. In Chinese context, the type of women's employment is a factor that affected women's fertility intentions: workers, civil/professionals, and business managers had the lowest fertility intentions, whereas farmers had the highest fertility intentions (Zheng and al., 2016). Many studies in developed countries found a negative relationship between fertility and women's labor force participation (Van and Maertens, 2015; Michaud \& Tatsiramos, 2011). However, evidence of negative effect of the number of children on women's labor force participation from developing countries at an early stage of demographic transition is less consistent (Agüero \& Marks, 2008). About mechanism of action of women's occupation on fertility, the first way is an income effect: female employment contributes to total household income, and additional income can be invested in raising more children or in improving childcare quality (Becker, 1960; Basu, 2006). This income effect can lead to increase or reduce fertility, but generally fertility drops if income rises (Galor and al., 2000). The other effect of women's occupation is also called substitution effect. In fact, employed women have a higher opportunity cost of raising children, and substitute productive labor for reproductive labor. This substitution effect results in decreased fertility (Van, 2015). Another mechanism of women's occupation on fertility is women's empowerment. Working outside the household and earning an own income empowers women. Through employment women widen their social network, which can lower fertility preferences and increase knowledge about birth control (Upadhay and al., 2010).

\section{Methodological Approaches}

\subsection{Conceptual Model}

The conceptual model we use to clarify whether fertility decline is explained by the differential distributions (composition effect and response effect) with focus on socioeconomic status (women's occupation; women's education; poverty) of fertility is the model of Davis and Blake (1956). According to this model, socioeconomic, cultural and environment variables affects fertility through others variables called intermediate variables. Due to difficulty to quantify the link between a set of intermediate fertility variables and fertility, this model has been improved by John Bongaarts $(1978,1982,2015)$ by defining proximate determinants. For the author, there are four fundamental elements: (i) exposure to sexuality; (ii) the use of contraception; (iii) the practice of abortion and (iv) postpartum infertility (related to breastfeeding). This framework of Bongaarts allows to analyze the factors of the evolution of fertility or its variations from one group to another. To each of these four elements is associated, an index and the total fertility rate would be the product of these four indices and the natural fertility rate. In the case of the present study, we made readjustments in the operationalization of this model particularly for proximate determinants. Instead of using marriage, we will introduce precocity and then, child marriage. Child marriage is defined as a union contracted before the age of 18. In addition, our database does not have information on abortions; its effect will therefore be integrated into that of contraception. The effect of breastfeeding will not be measured.

\subsection{Variables of Study}

\section{- Outcome}

Our outcome of interest is fertility decline between 2003 and 2015, determined by the difference between mean number of children in 2003 and 2015.

- Main independents variables

The main independents variable is socioeconomic status operationalized with three variables: (i) women's education (none, primary, secondary or more); (ii) women's occupation (no employment, service, trade, agriculture) and (iii) standard living of household (low, medium, high).

The standard living of household is used to approximate poverty and was measured by composite index information on housing characteristics of the household: the nature of the walls, roof and floor, light mode, the main source of supply of drinking water, type of toilet and type of fuel used for cooking food. Adopting a relative approach to poverty (Kobiané, 2004), we created the household wealth index specific to each place of residence using principal components analysis. 
The first component that explains a large proportion of the variance was retained as the synthetic index of the initial variables. Therefore, the composite index that was created represents a comfort indicator of housing, fair reflection of the socio-economic living standard of households (Kobiané, 2004), and indirectly that of household members.

- Intermediate variables

Two intermediate variables have been used due to availability of information in our databases. These variables are child marriage and contraceptive use.

- Variables of control

Based on the literature of fertility, other covariates have been considered in the model. These variables included religion, ethnicity, region of residence and, place of residence. Religion and ethnicity are considered in the analysis model regarding the cultural theories of demographic transition. The relationship between religion and fertility has been studied by many authors (Goldscheider, 1971; Baudin, 2015). The literature (Goldscheider, 1971) identifies four main hypotheses to explain the impact of religion on fertility: (i) the characteristic hypothesis, (ii) the particularized ideology hypothesis, (iii) the minority status hypothesis, and (iv) the socialization hypothesis. For Baudin (2015), the "attendance at religious services" variable is strongly significant but exhibits a smaller value than for the women's sub-sample: the highest differential fertility between strong religiousness and no religiousness equals $18.2 \%$. Ethnic differences in demographic behavior, particularly fertility have been interpreted through three hypotheses called the characteristics hypothesis and the "norms/cultural hypothesis" and the "minority hypothesis" (Goldscheider, 1971; Addai and Trovato, 1999). These hypotheses have been used to explain ethnic differences in fertility (Addai and Trovato, 1999; Palamuleni, 2014). Urbanization has emerged with the theory of demographic transition as a major determinant of change (Tabutin, 2003). Across sub-Saharan Africa, fertility is lower in urban areas (Shapiro and Tambashe, 2003; Talnan and Vimard, 2009).

\subsection{Data}

The data we use come from two national surveys: the 2003 demographic and health survey (DHS) and the 2015 demographic and health module of the Multisectoral Continuous Survey (EMC). These two surveys are representative at national level and at the thirteen administrative regions and provide detailed information on couples in particular as regards fertility, family planning, marriage and exposure to risk of pregnancy. The DHS concerned 12,477 women and EMC reached 11,504 women. These two surveys are realized by national institute of statistics and demography and comparable in terms of their methodology.

Even if, the two surveys are comparable because they use the same methodology (INSD, 2015), there are some differences between some groups (table 2). Indeed, there is an important decline of women with no education from $80.3 \%$ in 2003 to $71.8 \%$ in 2015 while the proportion of women with at least secondary education has increased from $8.7 \%$ in 2003 to $15.7 \%$ in 2015 . Huge changes have been also made according women's occupation. The percentage of women working in services has increased by 2.6 points of percentage while the percentage of traders has decreased from $16.1 \%$ in 2003 to $12 \%$ in 2015. More than half of women (51\%) got marriage before the age of 18 in 2003 compared to 2015 where the percentage of women who have been victim of child marriage is estimated to $43.2 \%$. The proportion of women aged $20-24$ rose from $18.2 \%$ to $14.9 \%$. According ethnicity, proportion of mossi also decreased from $56.4 \%$ to $51 \%$. The majority of women $(78.4 \%)$ live in rural areas. As for those with at least secondary education, they represented $8.7 \%$ in 2003 and 2015 the proportion is estimated at $15.7 \%$. Contraceptive use is relatively low (14\%) in 2003 but has improved significantly in 2015 (23.8\%). The distribution of women interviewed by religion indicates that the majority of women (60\%) practice the muslim religion. Data also confirmed $40.3 \%$ of women live in rich households. 
Table 1. Descriptive statistics for analysis variables among women aged between 15 and 49 in Burkina Faso, DHS 2003 and EMC-MDS 2015

\begin{tabular}{|c|c|c|c|c|c|}
\hline \multirow{2}{*}{ Characteristics } & \multicolumn{2}{|l|}{ Frequency } & \multirow{2}{*}{ Characteristics } & \multicolumn{2}{|l|}{ Frequency } \\
\hline & DHS 2003 & EMC 2015 & & DHS 2003 & EMC 2015 \\
\hline Women's education level & & & Religion & & \\
\hline None & 80.3 & 71.8 & No religion & 1.8 & 1.3 \\
\hline Primary & 11.0 & 12.4 & Christian & 28.2 & 30.4 \\
\hline Secondary and more & 8.7 & 15.7 & Muslim & 60.1 & 60.0 \\
\hline Women's occupation & & & Traditional & 9.9 & 0.1 \\
\hline No employment & 17.1 & 19.4 & Ethnicity & & \\
\hline Service & 2.3 & 4.9 & Bobo & 2.5 & 1.7 \\
\hline Trade & 16.1 & 12.0 & Dioula & 5.7 & 0.9 \\
\hline Agriculture & 65.5 & 63.7 & Peul-touareg & 7.6 & 8.7 \\
\hline Standard living of household & & & Gourmantché & 6.9 & 8.6 \\
\hline Low & 35.9 & 40.5 & Gourounsi & 3.3 & 4.7 \\
\hline Medium & 23.8 & 20.1 & Lobi & 5.2 & 3.5 \\
\hline High & 40.3 & 38.7 & Mossi & 56.4 & 51.0 \\
\hline Region of residence & & & Senoufo & 3.8 & 1.9 \\
\hline Boucle du Mouhoun & 7.3 & 9.5 & Bissa & 4.8 & 3.3 \\
\hline Cascades & 3.3 & 3.5 & Autre & 3.8 & 15.7 \\
\hline Centre & 13.4 & 12.4 & Child mariage & & \\
\hline Centre Est & 8.4 & 7.4 & No & 49.2 & 56.8 \\
\hline Centre Nord & 8.4 & 8.9 & Yes & 50.8 & 43.2 \\
\hline Centre Ouest & 7.2 & 8.6 & Contraceptive use & & \\
\hline Centre Sud & 5.9 & 4.9 & No & 86.0 & 76.2 \\
\hline Est & 7.2 & 10.1 & Yes & 14.0 & 23.8 \\
\hline Hauts Bassins & 12.9 & 9.3 & Age group & & \\
\hline Nord & 9.4 & 8.5 & $15-19$ & 22.3 & 21.0 \\
\hline Plateau Central & 5.0 & 5.0 & $20-24$ & 18.2 & 14.9 \\
\hline Sahel & 6.8 & 7.6 & $25-29$ & 16.6 & 17.7 \\
\hline Sud-Ouest & 4.8 & 4.2 & $30-34$ & 12.7 & 14.9 \\
\hline Place of residence & & & $35-39$ & 12.2 & 13.3 \\
\hline Urbain & 21.6 & 22.11 & $40-44$ & 9.6 & 9.8 \\
\hline \multirow[t]{2}{*}{ Rural } & 78.4 & 77.9 & $45-49$ & 8.4 & 8.4 \\
\hline & & & Total & 100 & 100 \\
\hline & & & Sample & 12477 & 11504 \\
\hline
\end{tabular}

Note: Proportions are weighted using sampling weights provided by the DHS and EMC-MDS

\subsection{Statistical Analysis Methods}

For data analysis, two methods of statistical analysis were used: the descriptive analysis and extension of the Blinder-Oaxaca (BO) decomposition. Descriptive analysis was used to examine the associations between each independent variable and the dependent variable namely the number of children per woman. Due to the quantitative nature of the dependent variable, we used the analysis of variance (ANOVA) in order to measure the degree of association of each independent variable with the dependent variable. Then, all variables significantly associated (table A3) are introduced in the model to explore the sources of fertility decline. 
The variables of analysis are common to both databases. They have been recoded to have the same modalities. Moreover, using two databases for two different periods, a new variable has been created in order to merge the database. The responses categories of this new variable called "time" is 1 if individuals provide for DHS 2003 and 0 if they provide to EMC 2015. We test the relationship between fertility and time variable using ANOVA and we find the association is very significant (table A1\&A2). That mean, the mean number of children per woman in 2003 and 2015 are statistically different. Then, it is possible to identify the source of the change in fertility.

We explored the sources of changes in fertility using an extension of the Blinder-Oaxaca (BO) decomposition (Blinder A., 1973; Oaxaca R., 1973). An extension of the Blinder-Oaxaca decomposition is a multivariate decomposition used the output from regression models to partition the components of a group difference in a statistic, such as a mean or proportion, into a component attributable to compositional differences between groups (differences in characteristics or endowments) and a component attributable to differences in the effects of characteristics (behavioral responses). The BO method allowed us to assess which factors were associated with each source of inequality (figure 1). Initially limited to continuous dependent variables, the BO decomposition approach has been extended to the case of non-linear dependent variables (Yun M-S, 2004).

To explain the technique (Powers DA, 2011), we begin with the standard problem of decomposing a difference in which the dependent variable is a function of a linear combination of predictors and regression coefficients: $Y=F(X \beta)$.

Where $Y$ is the $N .1$ dependent variable vector, $X$ is a $N . K$ matrix of independent variables, and $\beta$ is a $N .1$ vector of coefficients. $F$ can be linear, logit, Probit, Poisson, negative binominal functions. The mean difference in $Y$ between groups $A$ and $B$ can be decomposed as:

$$
\begin{gathered}
\left.\left.\overline{Y_{A}}-\overline{Y_{B}}=\overline{F\left(X_{A} \beta_{A}\right.}\right)-\overline{F\left(X_{B} \beta_{B}\right.}\right) \\
\left.\left.=\left(\overline{F\left(X_{A} \beta_{A}\right.}\right)-\overline{F\left(X_{B} \beta_{A}\right)}\right)+\left(\left(\overline{F\left(X_{B} \beta_{A}\right.}\right)-\overline{F\left(X_{B} \beta_{B}\right.}\right)\right)
\end{gathered}
$$

With

$$
\begin{aligned}
& E=\overline{F\left(X_{A} \beta_{A}\right)}-\overline{F\left(X_{B} \beta_{A}\right)} \\
& C=\overline{F\left(X_{B} \beta_{A}\right)}-\overline{F\left(X_{B} \beta_{B}\right)}
\end{aligned}
$$

The component $E$ refers to the part of the differential attributable to differences in characteristics the $\mathrm{C}$ component refers to the part of the differential attributable to differences in coefficients or effects. Group $A$ as the comparison group and group $B$ as the reference group. To have the unique contribution of each predictor to each component, we have to partition $E$ and $C$ into portions, $E_{k}$ and $C_{k}(k=1, \ldots, K)$, that represent the unique contribution of the $k^{\text {th }}$ covariate to $E$ and $C$, respectively with

$$
\overline{Y_{A}}-\overline{Y_{B}}=E+C=\sum_{k=1}^{K} W_{\Delta X_{k}} E+\sum_{k=1}^{K} W_{\Delta \beta_{k}} C=\sum_{k=1}^{K} E_{k}+\sum_{k=1}^{K} C_{k}
$$

Weights is obtained Using from a first-order Taylor linearization of (1) around $X_{A} \beta_{A}$ and $X_{B} \beta_{B}$ (Powers DA, 2011). After linearization, the weight component is:

$$
W_{\Delta_{X_{k}}}=\frac{\beta_{A_{k}}\left(\bar{X}_{A_{k}}-\bar{X}_{B_{k}}\right)}{\sum_{k=1}^{K} \beta_{A_{k}}\left(\bar{X}_{A_{k}}-\bar{X}_{B_{k}}\right)} \quad W_{\Delta_{\beta_{k}}}=\frac{\bar{X}_{A_{k}}\left(\beta_{A_{k}}-\beta_{B_{k}}\right)}{\sum_{k=1}^{K} \bar{X}_{A_{k}}\left(\beta_{A_{k}}-\beta_{B_{k}}\right)}
$$

Where

$$
\sum_{k=1}^{K} W_{\Delta X_{k}}=\sum_{k=1}^{K} W_{\Delta \beta_{k}}=1
$$


The composition weights $W_{\Delta X_{k}}$ reflect the contribution of the $k^{\text {th }}$ covariate to the linearization of $E$ as determined by the magnitude of the group difference in means weighted by the reference group's effect. The coefficient weights $W_{\Delta \beta_{k}}$ reflect covariate $k$ 's contribution to the linearization of $C$ as determined by the magnitude of the group difference in the effects weighted by the comparison group's mean. A normalized equation is then computed to identify the intercept and coefficients of all dummy variables, including reference groups (Powers DA, 2011).

The percentage of fertility decline explained by a given component for each risk factor is defined by the amount of the difference in total fertility rate explained by the component divided by the total difference in total fertility rate between 2003 and 2015 multiplied by 100. Estimates were obtained using the statistical routine designed for non-linear outcomes described by Powers, Yoshioka and Yun (Powers DA, 2011). This approach overcomes potential problems related to path dependence and identification (Powers DA, 2011). All analyses, both descriptive and multivariate, were weighted using the available DHS sampling weights and accounted for clustering at the household level. We used STATA version 13 software for all analyses.

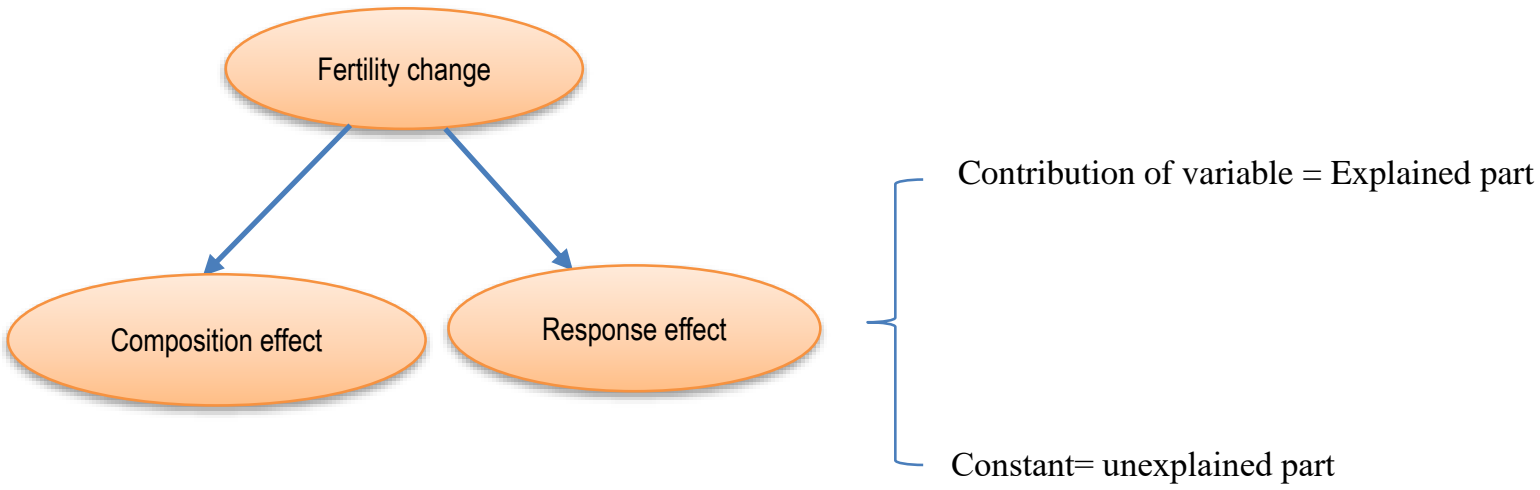

Figure 1. Schematization of decomposition

\section{Results and Interpretations}

The decline in fertility observed between 2003 and 2015 is mainly due to changes in the distribution of women of childbearing age (Table 2). Indeed, the composition effect represents $88 \%$ and only $12 \%$ for the response effect. Regarding the results of $\mathrm{BO}$ decomposition, it is possible to constitute three groups of variables: (i) those for which the composition effect and response effect are positive (women's education, women's occupation, standard living of household); (ii) those with a positive composition effect and a negative response effect (region of residence, place of residence, religion, child marriage) and (iii) those with a negative composition effect and a positive response effect (contraceptive use, ethnicity, age). Globally, the first group has contributed to reduce the fertility gap between 2003 and 2015.

Differences in the distribution of women's education level explained $17.33 \%$ of fertility gap between 2003 and 2015 . This result indicates that, if women distribution in 2003 of education level was the same as in 2015 distribution, the expected reduction of fertility differential between two periods would be estimated to $17.33 \%$. From 2003 to 2015, the percentage of women who reported they have no education decrease from $80.3 \%$ to $71.8 \%$ and those who have at least secondary level increase from $8.7 \%$ to $15.7 \%$. Thus, results from the BO decomposition imply $8.06 \%$ decrease in fertility gap if the percentage of women with no education in 2003 was equal to that of 2015. Changes in percentage of women with at least secondary education level have also contributed to reduce fertility gap by $9.52 \%$. Examining the response effect, we note that if women with at least secondary education level in 2003 had the same fertility behavior than the counterparts in 2015, the expected increase of fertility gap would be estimated to $3.51 \%$. This result implies women's with at least secondary education level fertility behavior resulted fertility decline. These results confirmed those of descriptive analysis (Table A3) for which parity of women with at least secondary education level increase from 0.92 in 2003 to 0.79 in 2015 . All other things being equal, it can be said the distribution of women according education level did not favor in fertility decline, while education induced changes in women's fertility behavior that led fertility decline particularly for women with at least secondary education level.

According to women's occupation, composition effect is estimated to $67.64 \%$ compared with response effect estimated to $30.86 \%$. Thus, we note that if distribution according this variable was invariant in time, we would register $67.64 \%$ decrease of fertility gap. This expected decrease would be $30.86 \%$ if women's fertility behavior in 2003 remains the 
same in 2015. The profile of women who contributed to the changes of fertility was those working in service and agriculture. The percentage of women working in agriculture decrease by two points of percentage and those who working in service increase from $2.3 \%$ to $4.9 \%$. The expected decrease of fertility gap would be $50.96 \%$ if the percentage was invariant and $6.44 \%$ if the percentage of agriculture was also invariant. The response effect indicates if women who working in agriculture field in 2003 had the same fertility behavior with their counterpart in 2015, we would have $69.19 \%$ decrease of fertility gap. However, we would register $54.35 \%$ increase of fertility gap if women's fertility behavior during the two periods (2003 and 2015) was similar. According to these results, changes in percentage of women who working in agriculture field and service have contributed to reduce fertility gap while the behavior of those who working in service contributed to increase fertility. Thus, only, women working in service who have contributed to fertility decline because of changes in fertility behavior.

For household standard living, response effect is estimated to $3.17 \%$ and composition represent only $0.16 \%$. Women from low and high household standard living are those who have more contributed to the changes in fertility. For example, regarding response effect, women from low household standard living contributed to increase fertility gap between 2003 and 2015. However, women from high standard living contributed to reduce the fertility gap. Indeed, if this category of women in 2003 had the same fertility behavior with their counterparts in 2015, the expected decrease in fertility gap from women with high standard living of household level would be $20 \%$ while the expected increase from women with low standard living of household would be $15.32 \%$.

Differences in the distribution of region of residence, as well as the place of residence, religion, and ethnicity have contributed to reduce fertility gap while differences in distribution of age and contraceptive use have strengthened fertility decline between 2003 and 2015. For example, if the distribution of women according place of residence in 2003 was the same as in 2015 , the expected reduction of fertility gap would be $4.27 \%$. The observed changes in fertility decline are also partly explained by the different fertility behavior. Overall, women's fertility behavior in different regions, place of residence, child marriage and religion have contributed to fertility decline. Women from rural area and those from regions of Sahel and Est and also Muslim are those who had more contribute to fertility decline. 
Table 2. Results from Blinder-Oaxaca decomposition (BO) analysis of fertility decline between 2003 and 2015

\begin{tabular}{|c|c|c|c|c|c|c|}
\hline \multirow{2}{*}{ Variable } & \multicolumn{3}{|c|}{ Composition effect } & \multicolumn{3}{|c|}{ Response effect } \\
\hline & Coefficient & $\mathrm{P}$-value & $\%$ & Coefficient & P-value & $\%$ \\
\hline Composition effect & 0.22 & 0.000 & 87.95 & & & \\
\hline Response effect & & & & 0.03 & 0.337 & 12.05 \\
\hline Education level & & & 17.33 & & & 0.20 \\
\hline None & 0.02 & 0.000 & 8.06 & 0.00 & 0.917 & 1.38 \\
\hline Primary & 0.00 & 0.034 & -0.25 & 0.01 & 0.38 & 2.33 \\
\hline Secondary and more & 0.02 & 0.000 & 9.52 & -0.01 & 0.364 & -3.51 \\
\hline Women's occupation & & & 67.64 & & & 30.86 \\
\hline No employment & 0.00 & 0.000 & -0.60 & 0.04 & 0.055 & 14.21 \\
\hline Service & 0.13 & 0.000 & 50.96 & -0.14 & 0.042 & -54.35 \\
\hline Trade & 0.03 & 0.000 & 10.83 & 0.00 & 0.251 & 1.81 \\
\hline Agriculture & 0.02 & 0.000 & 6.44 & 0.17 & 0.041 & 69.19 \\
\hline Standard living of household & & & 0.16 & & & 3.17 \\
\hline Low & 0.00 & 0.725 & 0.00 & -0.04 & 0.067 & -15.32 \\
\hline Medium & 0.00 & 0.569 & 0.12 & 0.00 & 0.584 & -1.46 \\
\hline High & 0.00 & 0.395 & 0.03 & 0.05 & 0.042 & 19.96 \\
\hline Region of residence & & & 0.28 & & & -0.32 \\
\hline Boucle du Mouhoun & 0.00 & 0.000 & -1.93 & 0.01 & 0.437 & 2.17 \\
\hline Cascades & 0.00 & 0.015 & 1.15 & 0.00 & 0.575 & 1.16 \\
\hline Centre & 0.00 & 0.000 & 0.02 & 0.02 & 0.125 & 6.25 \\
\hline Centre Est & 0.00 & 0.059 & 0.56 & -0.01 & 0.445 & -2.00 \\
\hline Centre Nord & 0.00 & 0.000 & -0.59 & -0.01 & 0.252 & -2.46 \\
\hline Centre Ouest & 0.00 & 0.561 & 0.26 & 0.02 & 0.06 & 8.23 \\
\hline Centre Sud & 0.00 & 0.000 & 0.84 & -0.02 & 0.045 & -7.80 \\
\hline Est & 0.00 & 0.567 & -0.39 & -0.03 & 0.059 & -12.99 \\
\hline Hauts Bassins & 0.00 & 0.238 & 0.01 & 0.00 & 0.995 & 0.02 \\
\hline Nord & 0.00 & 0.319 & -0.43 & 0.01 & 0.145 & 5.35 \\
\hline Plateau Central & 0.00 & 0.000 & -1.30 & 0.00 & 0.927 & 0.19 \\
\hline Sahel & 0.00 & 0.154 & -0.53 & -0.02 & 0.046 & -9.26 \\
\hline Sud-Ouest & 0.01 & 0.004 & 2.61 & 0.03 & 0.042 & 10.83 \\
\hline Place of residence & & & 4.27 & & & -11.01 \\
\hline Urban & 0.01 & 0.000 & 2.13 & 0.02 & 0.421 & 6.66 \\
\hline Rural & 0.01 & 0.000 & 2.13 & -0.04 & 0.421 & -17.67 \\
\hline Religion & & & 1.05 & & & -18.47 \\
\hline No religion & 0.00 & 0.498 & -0.17 & 0.00 & 0.456 & 0.54 \\
\hline Christian & 0.00 & 0.674 & -0.28 & 0.00 & 0.839 & -1.30 \\
\hline Muslim & 0.00 & 0.774 & 0.22 & -0.04 & 0.354 & -16.72 \\
\hline Traditional & 0.00 & 0.070 & 1.28 & 0.00 & 0.635 & -1.00 \\
\hline Ethnicity & & & -6.66 & & & 5.90 \\
\hline Bobo & 0.00 & 0.407 & -0.27 & 0.00 & 0.209 & 1.46 \\
\hline Dioula & 0.01 & 0.056 & 2.42 & 0.00 & 0.196 & 0.95 \\
\hline Peul-touareg & 0.00 & 0.059 & -1.00 & 0.01 & 0.148 & 5.55 \\
\hline Gourmantché & 0.00 & 0.646 & -0.17 & -0.01 & 0.395 & -3.12 \\
\hline Gourounsi & 0.00 & 0.820 & -0.24 & 0.00 & 0.856 & 0.35 \\
\hline Lobi & -0.02 & 0.000 & -6.16 & -0.02 & 0.079 & -6.69 \\
\hline Mossi & 0.00 & 0.000 & 0.77 & 0.02 & 0.442 & 7.31 \\
\hline Senoufo & 0.00 & 0.556 & 0.66 & 0.00 & 0.179 & -1.34 \\
\hline Bissa & 0.00 & 0.164 & -0.28 & 0.00 & 0.841 & -0.29 \\
\hline Autre & -0.01 & 0.562 & -2.38 & 0.00 & 0.753 & 1.73 \\
\hline Child mariage & 0.07 & 0.000 & 26.64 & -0.03 & 0.211 & -12.10 \\
\hline Contraceptive use & -0.02 & 0.000 & -6.64 & 0.00 & 0.76 & 1.40 \\
\hline Age & -0.04 & 0.000 & -16.50 & 0.92 & 0.098109 & 364.31 \\
\hline Constant & & & & -0.88 & -1.5616 & -351.88 \\
\hline
\end{tabular}

Note: Using this method, the net percent contribution of both components always equals to 100 . A contribution may be negative (less than zero) or positive and can even exceed 100. A positive contribution indicates the expected decrease in fertility gap between 2003 and 2015, whereas a negative contribution indicates the opposite. 


\section{Discussions and Conclusions}

So far, no study concerning Burkina Faso has been interested in the decomposition of fertility, this paper contribute to fill this gap. Moreover, our study integrated time dimension in the analysis by using a decomposition of the fertility gap observed between 2003 and 2015. The results (table 3) show that the observed change in terms of fertility decline is more attributable to the composition effect $(88 \%)$ than behavioral effect $(12 \%)$. Our results show a significant contribution of the socio-economic variables in particular women's occupation and education. The composition effect of socioeconomic factors is estimated to $85.13 \%$ and the response effect is $34.23 \%$. The proximate determinants according to Bongaarts model have relatively low contributions: $20 \%$ for the composition effect and $10.7 \%$ for the response effect. Overall, socio-economic factors contributed to the reduction of the fertility gap between 2003 and 2015; they have contributed to maintaining fertility at a high level.

Table 3. Composition and response effect by group of variables

\begin{tabular}{lll}
\hline Type of variable & Composition effect $(\%)$ & Response effect $(\%)$ \\
\hline Socioeconomic variable & 85.13 & 34.23 \\
Cultural variable & 20.0 & -10.7 \\
Bongaarts proximate determinants & -5.61 & -12.57 \\
Geographic variable & 4.55 & 11.33 \\
Age & -16.5 & 364.31 \\
Constant & & -351.88 \\
Total & 87.95 & 12.05 \\
\hline
\end{tabular}

Descriptive analyzes show that fertility decreases as women's educational attainment increases (Table A3). Thus, there appears to be a negative relationship between women's education and fertility (Doliger, 2004, Brzozowska, 2015; Behrman, 2015). Estimates of the contribution of women's education in the explanation of fertility decline between 2003 and 2015 show that while the distribution of women by education in 2003 remained the same in 2015 , the fertility gap between these periods would be decrease by $17.33 \%$, mainly due to women with no education $(8.06 \%)$ and those with at least secondary education level $(9.52 \%)$. The decline in the proportion of women with no education to those who have primary or at least secondary level (table 1) has contributed to reduce fertility decline between 2003 and 2015. However, the analysis of response effect relative to women's education indicates that if women had the same fertility behavior, those who have at least secondary education would contribute to greater fertility gap by $3.51 \%$. Schooling is considered to be the main channel for disseminating modern values in developing countries and strong predictor of the general level of fertility in developing countries because it contributes to improve an individual's knowledge (Bongaarts, 2003; Doliger, 2004). Thus, our study confirms the past results because behavioral changes have favored fertility decline, particularly for those with at least secondary education.

Analysis by women's occupation indicates that this variable has the largest contribution to fertility decline between 2003 and 2015. In fact, the composition effect relative to women's occupation is $67.64 \%$ (Table 2). Thus, shifting the women's distribution according women's occupation in 2015 to 2003 would provide a largest decrease to fertility gap; the decline in fertility is less important due to those working in trade and agriculture. In terms of composition, women working in the agriculture field, traders and those working in services have contributed to reduce fertility decline. Similar results were found by Zheng et al. (2016) in the Chinese context. In addition, fertility behaviors according to women's occupation have also evolved, especially among women working in the trade; which has favored the fertility decline. The response effect of women's occupation estimated to $30.86 \%$ indicates that if the women in 2015 had the same fertility behaviors as those of 2003 , the fertility gap for the period would also be reduced by $30.86 \%$ (Table 2 ). In terms of behavior, women working in agriculture also contributed to the reduction of fertility gap, while those employed in services helped to increase fertility gap. The relationship between women's occupation and fertility is quite mixed in the literature (Schockaert, 2005). However, it should be noted that many studies have concluded that women's participation in the labor market in developed countries favors lower fertility (Van and Maertens, 2015; Michaud \& Tatsiramos, 2011). In developing countries like Burkina Faso, the evidence on this relationship is not consistent (Agüero \& Marks, 2008 ). The United Nations (1987) study based on global fertility surveys of the 1970s estimates the effect of female employment type on fertility. The results diverge quite strongly from one country to another. However, modern and mixed-type women's jobs still have a more negative effect on fertility and stronger than other types of work. This result confirms our finding relative to response effect about women working in service who have contributed to fertility decline.

As for the standard of living of the household, which can approximate household income, it is an important factor in fertility regarding Easterlein's theory. Analyzes indicate a weak composition effect compared to response effect that has been estimated at $3.17 \%$. This reflects differential fertility patterns for women from low standard living of household, medium and high standard living of household. Indeed, we observed that if women from high standard living of household in 2015 had the same fertility behavior as their counterparts in 2003, the observed fertility gap would be reduced by $20 \%$. This category of women has therefore contributed to reduce fertility decline during the period. Considering women from low standard living of household, their behavior has contributed to increase fertility gap and 
then to maintain fertility decline. So, there is a negative relationship between standard of living of the household and fertility (Table A3) but, the behavior of those from the less affluent households contributed to the decline in fertility while those from the wealthier households contributed to the increase in fertility. These results confirm those found by Talnan and Vimard (2003). However, this conclusion should be nuanced (Garganta et al., 2016).

Geographic variables such as region of residence and place of residence as well as cultural variables (religion, ethnicity) determine fertility but the effect appears to be less important. For each of these variables, the composition effect is positive but the response effect is negative. Fertility behaviors evolved by region and place of residence; they also involved by religion and this contributed to fertility decline. Analyzing ethnicity, we found that composition effect is negative and response effect is positive. In other words, if the distribution of women by ethnicity in 2015 was similar to that in 2003 , fertility gap would be increased by $6.66 \%$, but it would be decrease by $5.90 \%$ if the fertility behaviors of women in 2015 remained the same in 2003. The effect of geographic and cultural variables could be related to the level of development of these spheres which in turn induces cultural changes that influence fertility behaviors; and then fertility decline (Tabutin, 2003; Talnan and Tabutin, 2009).

Shifting women's distribution on contraceptive use of 2015 to 2003 levels would contribute to increase the fertility gap by $6.64 \%$. That mean that women's distribution on contraceptive use contribute to fertility decline during the period. According the child marriage, the analysis of composition effect shows if child marriage remained the same level, fertility gap would be decrease by $26.64 \%$. Child marriage has therefore contributed to increase fertility. However, response effect shows that women's behavior on child marriage relatively to fertility contribute to increase fertility gap by $12.1 \%$. Women's behavior on child marriage towards fertility favored fertility decline. It may be explaining partly the fact the marriage is no longer immediately followed by fertility.

At the end of the study, we noted that women who had the most contribution to fertility decline between 2003 and 2015 are:

- Women with at least secondary education, working in services or residing in the least affluent households. In addition, these women are those residing in rural area and regions of Est and Sahel. They practice muslim religion and also use modern methods of contraception.

- Women who contributed to increase fertility are women with no education and working in the trade and agriculture sector. They come from households with high standard living and also from the region of SudOuest. In addition, these women are victims of child marriage.

In the light of the results obtained, it is important on the perspective to harness demographic dividend to (i) encourage girl's education by enrolling them in school but particularly by ensuring that they go at least to secondary school; (ii) create a minimum package of services for the promotion of modern methods of contraception, particularly for women working in agriculture and trade sector as well as those from poor households and living in rural areas; (iii) promote domestic work to allow more women to be interested.

Several recent research in Africa are focus on how to harness demographic dividend. The assumption is the harnessing of demographic dividend will contribute to improve the population well-being, but in what extent the demographic dividend would have to improve population well being remains unknown.

\section{Appendices}

Table A1. Summary of depend variable (number of children)

\begin{tabular}{llll}
\hline Time variable & Mean & Standard Deviation & Frequency \\
\hline 0 & 3.0763213 & 2.710927 & 11504 \\
1 & 3.327723 & 2.9962965 & 12477 \\
Total & 3.2071223 & 2.8656476 & 23981 \\
\hline
\end{tabular}

Table A2. Results of Analysis of Variance

\begin{tabular}{llllll}
\hline Source & SS & df & MS & F & Prob $>$ F \\
\hline Between groups & 378.292983 & 1 & 378.292983 & 46.15 & 0.0000 \\
Within groups & 196543.931 & 23979 & 8.19650238 & & \\
Total & 196922.224 & 23980 & 8.21193593 & & \\
\hline
\end{tabular}

Bartlett's test for equal variances: $\quad$ chi2 $(1)=119.3774$, Prob $>$ chi2 $=0.000$ 
Table A3. Analysis of variance between fertility and the covariables

\begin{tabular}{|c|c|c|c|c|}
\hline \multirow{2}{*}{ Variable } & \multicolumn{2}{|c|}{ DHS 2003} & \multicolumn{2}{|c|}{ EMC 2015} \\
\hline & Parity & Fischer coefficient & Parity & Fischer coefficient \\
\hline \multicolumn{5}{|l|}{ Education level } \\
\hline None & 3.79 & & 3.85 & \multirow{3}{*}{$975.17 * * *$} \\
\hline Primary & 2.0 & $454.93 * * *$ & 1.94 & \\
\hline Secondary and more & 0.92 & & 0.79 & \\
\hline \multicolumn{5}{|l|}{ Women's occupation } \\
\hline No employment & 1.55 & & 1.42 & \multirow{4}{*}{$739.07 * * *$} \\
\hline Service & 1.78 & $23035 * * *$ & 1.10 & \\
\hline Trade & 3.27 & 200.00 & 2.25 & \\
\hline Agriculture & 3.8 & & 3.95 & \\
\hline \multicolumn{5}{|l|}{ Standard living of household } \\
\hline Low & 3.75 & & 3.58 & \multirow{3}{*}{$190.77 * * *$} \\
\hline Medium & 3.57 & $128.86^{* * *}$ & 3.29 & \\
\hline High & 2.82 & & 2.52 & \\
\hline \multicolumn{5}{|l|}{ Region of residence } \\
\hline Boucle du Mouhoun & 4.04 & \multirow{13}{*}{$18.09 * * *$} & 3.6 & \multirow{13}{*}{$35.08 * * *$} \\
\hline Cascades & 3.38 & & 2.87 & \\
\hline Centre & 2.46 & & 1.83 & \\
\hline Centre Est & 3.21 & & 2.92 & \\
\hline Centre Nord & 3.35 & & 3.35 & \\
\hline Centre Ouest & 3.49 & & 2.73 & \\
\hline Centre Sud & 3.06 & & 3.08 & \\
\hline Est & 3.4 & & 3.87 & \\
\hline Hauts Bassins & 2.84 & & 3.01 & \\
\hline Nord & 3.37 & & 3.1 & \\
\hline Plateau Central & 3.36 & & 3 & \\
\hline Sahel & 3.70 & & 3.72 & \\
\hline Sud-Ouest & 3.72 & & 2.87 & \\
\hline \multicolumn{5}{|l|}{ Place of residence } \\
\hline Capital & 1.75 & \multirow{4}{*}{$262.88 * * *$} & 1.59 & \multirow{4}{*}{$315.64 * * *$} \\
\hline Small town & 2.45 & & 2.25 & \\
\hline Rural & 3.66 & & 3.45 & \\
\hline Religion. & & & & \\
\hline No religion & 3.6 & & 2.99 & \\
\hline Christian & 2.99 & $58.18 * * *$ & 2.74 & $30 * * *$ \\
\hline Muslim & 3.31 & & 3.15 & \\
\hline Traditional & 4.18 & & 3.78 & \\
\hline Ethnicity & & & & \\
\hline Bobo & 2.99 & & 2.6 & \\
\hline Dioula & 3.36 & & 2.46 & \\
\hline Peul-touareg & 3.56 & & 3.52 & \\
\hline Gourmantché & 3.43 & & 3.77 & \\
\hline Gourounsi & 3.17 & $3.05 * * *$ & 2.64 & $14.48 * * *$ \\
\hline Lobi & 3.58 & & 2.85 & 14.40 \\
\hline Mossi & 3.27 & & 3.02 & \\
\hline Senoufo & 3.4 & & & \\
\hline Bissa & 3.14 & & 2.5 & \\
\hline Autre & 3.55 & & 3.13 & \\
\hline Child mariage & & & & \\
\hline No & 2.30 & $1673.3 * * *$ & 2.32 & $1404 * * *$ \\
\hline Yes & 4.36 & & 4.13 & \\
\hline Contraceptive use & & & & \\
\hline $\begin{array}{l}\text { No } \\
\text { Yes }\end{array}$ & $\begin{array}{l}3.37 \\
2.95\end{array}$ & $22.9 * * *$ & 3.41 & $44.19 * * *$ \\
\hline $\begin{array}{l}\text { Yes } \\
\text { Age group }\end{array}$ & 2.95 & & & \\
\hline $15-19$ & 0.19 & & 0.15 & \\
\hline $20-24$ & 1.37 & & 1.29 & \\
\hline $25-29$ & 2.96 & & 2.75 & \\
\hline $30-34$ & 4.37 & $4667.16^{* * *}$ & 4.03 & $3604.10 * * *$ \\
\hline $35-39$ & 5.76 & & 5.16 & \\
\hline $40-44$ & 6.61 & & 6.08 & \\
\hline 45-49 & 7.30 & & 6.32 & \\
\hline Total & 3.33 & & 3.07 & \\
\hline
\end{tabular}

Note: $* * * \mathrm{p}<=0.001 ; * * 0.001<\mathrm{p}<=0.05 ; * 0.05<\mathrm{p}<=0.01$. 


\section{References}

Aassve, A., Kedir, A. M., \& Woldegebrie, H. T. (2006). State Dependence and Causal Feedback of Poverty and Fertility in Ethiopia. In Working Paper, No. 30, Institute for Social and Economic Research. Colchester: University of Essex.

Addai, I., \& Trovato, F. (1999). Structural assimilation and ethnic fertility in Ghana. Journal of Comparative Family Studies, 30(3), 409-427.

Agüero, J. M., \& Marks, M. S. (2008). Motherhood and female labor force participation: Evidence from infertility shocks. American Economic Review, 98 (2), 500-504. https://doi.org/10.1257/aer.98.2.500

Ainsworth, M. (1989). Socioeconomic determinants of fertility in Côte d'Ivoire. Living standard measurement study. In working paper, No. 53, The World Bank, Washington, D.C.

Appleton, S. (1996). How does female education affect fertility? A structural model for the Côte D'Ivoire. Oxford Bulletin of Economics and Statistics.

Basu, K. (2006). Gender and Say: a Model of Household Behavior with Endogenously Determined Balance of Power. Econ J, 116(511), 558-580. https://doi.org/10.1111/j.1468-0297.2006.01092.x

Baudin, T. (2015). Religion and fertility: The French connection. Demographic Research, 32(13), 397-420. https://doi.org/10.4054/DemRes.2015.32.13

Becker, G. S. (1965). A Theory of the Allocation of Time. The Economic Journal, 75(299), 493-517. https://doi.org/10.2307/2228949

Becker, G. S., \& Lewis, H. G. (1973). On the Interaction between the Quantity and Quality of Children. Journal of Political Economy, 81, 279-288. https://doi.org/10.1086/260166

Becker, G. S. (1960). An Economic Analysis of Fertility. Chapters, in: Demographic and Economic Change in Developed Countries. National Bureau of Economic Research, 209-240.

Behrman, J. A. (2015). Does Schooling Affect Women's Desired Fertility? Evidence from Malawi, Uganda, and Ethiopia. Demography, 52(3), 787-809. https://doi.org/10.1007/s13524-015-0392-3

Behrman, J., \& Rosenzweig, M. R. (2002). Does Increasing Women's Schooling Raise the Schooling of the Next Generation? American Economic Review, 92(1), 323-334. https://doi.org/10.1257/000282802760015757

Blinder, A. (1973). Wage discrimination: reduces form and structural estimates. J Hum Resource; 8(4), 436-55. https://doi.org/10.2307/144855

Bongaarts, J. (1978). A framework for analyzing the proximate determinants of fertility. Population and Development Review, 4(1), 105-132. https://doi.org/10.2307/1972149

Bongaarts, J. (1982). The fertility-inhibiting effects of the intermediate fertility variables. Studies in Family Planning, 13(6/7), 178-189. https://doi.org/10.2307/1965445

Bongaarts, J. (2003). Completing the Fertility Transition in the Developing World: The Role of Educational Differences and Fertility Preferences. Policy Research Division Working Papers, N0277. https://doi.org/10.1080/0032472032000137835

Bruce, J., \& Bongaarts, J. (2010). The new population challenge, A Pivotal Moment: Population, Justice, and the Environmental Challenge. Covelo, CA: Island Press, 260-275.

Bruce, J., \& Bongaarts, J. (2015). Modeling the fertility impact of the proximate determinants: Time for a tune-up. Demographic Research, 33(19), 535-560.

Brzozowska, Z. (2015). Fécondité et niveau d'instruction des femmes pendant le socialisme d'État en Europe centrale et orientale. Population, 70, 731-769.

Chicoine, L. (2012). Education and Fertility: Evidence from a Policy Change in Kenya. IZA Discussion Paper No. 6778 .

Currie, J., \& Moretti, E. (2003). Mother's education and the intergenerational transmission of human capital: Evidence from college openings. Quarterly Journal of Economics.

Dakuyo, L. M., Koné, M., \& Wetta, C. (2010). Réflexion sur les défis de la croissance démographique au Burkina Faso, «Vision Burkina 2025».

Davis, K., \& Blake, J. (1956). Social structure and fertility: An analytic framework. Economic Development and Cultural Change, 4(3), 211-23. https://doi.org/10.1086/449714 
Doliger, C. (2004). Le rôle de l'éducation dans la baisse de la fécondité d'après*guerre. LAMETA working paper, 2004-11

Easterlin, R. A. (1969). Population, Labor Force, and Long Swings in Economic Growth: the American Experience. New York, Colombia University Press.

Easterlin, R. A. (1973). Relative Economic Status and the American Fertility Swing, dans E.B. Sheldon (ed.). Family Economic Behavior: Problems and Prospects, Philadelphia, J. B. Lippincott, R. Hill et D.M. Klein, 170-223.

Easterlin, R. A. (1980). Birth and Fortune: The Impact of Numbers on Personal Welfare. New York, Basic Books

Finlay, J. E., Mejía-Guevara, I., \& Akachi Y. (2018) Inequality in total fertility rates and the proximate determinants of fertility in 21 sub-Saharan African countries. PLoS ONE, 13(9). https://doi.org/10.1371/journal.pone.0203344

Galor, O., \& Weil, D. N. (2000). Population, technology, and growth: From Malthusian stagnation to the demographic transition and beyond. Am Econ Rev, 90(4), 806-828. https://doi.org/10.1257/aer.90.4.806

Garganta, S., Gasparini, L., Marchionni, M., \& Tappata, M. (2016). The Effect of Cash Transfers on Fertility: Evidence from Argentina. Population Policy Rev, 36, 1-24. https://doi.org/10.1007/s11113-016-9417-x

Goldscheider, C. (1971). Population, Modernization and Social Structure. Boston, MA: Little, Brown and Company.

Guiella, G., \& Poirier, J. (2000). Fondements socio-économiques de la fécondité chez les Mossis du plateau central (Burkina Faso). in Pilon M. et Guillaume A. (éds), Maîtrise de la fécondité et planification familiale au Sud. IRD, Paris: 93-110.

Institut National de la Statistique et de la Démographie (2004). Enquête burkinabé sur les conditions de vie des ménages (EBCVM). Rapport d'analyse, $44 \mathrm{p}$.

Institut National de la Statistique et de la Démographie (2015). Résultats préliminaires de l'enquête Multisectorielle Continue, Module démographie et santé.

Institut National de la Statistique et de la Démographie (2015). Profil de pauvreté et d'inégalités. Rapport de l'enquête Multisectorielle Continue 2014, 90p.

Institut National de la Statistique et de la Démographie (2015). Le profil de pauvreté au Burkina Faso. Rapport de l'enquête prioritaire de 1994, 192p.

Institut National de La Statistique Et de La Démographie et Orc Macro (2004). Enquête démographique et de santé du Burkina Faso 2003, Calverton, Maryland (USA) : INSD et ORC Macro., 455 p.

Kiersten, J., Abderrahim, N., \& Rutstein, S. O. (2011). Changes in the Direct and Indirect Determinants of Fertility in Sub-Saharan Africa. DHS Analytical Studies No. 23. Calverton, Maryland, USA: ICF Macro.

Kim, J. (2010). Women's education and fertility: An analysis of the relationship between educations and birth spacing in Indonesia. Economic Development and Cultural Change. https://doi.org/10.1086/649638

Kim, J. (2016). Female education and its impact on fertility, IZA World of Labor, ISSN 2054-9571. Institute for the Study of Labor (IZA), Bonne, Iss. 228

Kobiané, J. F. (2004). Habitat et biens d'équipement comme indicateurs de niveau de vie des ménages. Bilan méthodologique et application à l'analyse de la relation pauvreté/scolarisation. Étude de la Population Africaine, 19, Supplément A, 265-282.

Lavy, V., Silva, O., \& Weinhardt, F. (2011). The Good, the Bad, and the Average: Evidence on Ability Peer Effects in Schools. Journal of Labor Economics, 30(2), 367-414

Lee, R., \& Mason, A. (2010). Fertility, Human Capital, and Economic Growth over the Demographic Transition. European Journal of Population; 26(2), 159-182. https://doi.org/10.1007/s10680-009-9186-x

Lee, R., \& Mason, A. (2016). Conséquences macroéconomiques du vieillissement de la population. Rev Econ Finance, 122(2), 83-101. https://doi.org/10.3917/ecofi.122.0083

Lee, R., \& Mason, A. (2010). Fertility, Human Capital, and Economic Growth over the Demographic Transition. European Journal of Population, 26(2), 159-182. https://doi.org/10.1007/s10680-009-9186-x

Lutz, W. (1987). Factors Associated with the Finnish Fertility Decline Since 1776. Population Studies, 41(3), 463-482. https://doi.org/10.1080/0032472031000143006

Matovu, J. K. B., Makumbi, F., Wanyenze, R. K., \& Serwadda, D. (2017). Determinants of fertility desire among married or cohabiting individuals in Rakai, Uganda: a cross-sectional study. Reproductive Health, 14(2). https://doi.org/10.1186/s12978-016-0272-3 
Michaud, P. C., \& Tatsiramos, K. (2011). Fertility and female employment dynamics in Europe: the effect of using alternative econometric modeling assumptions. Journal of Applied Econometrics, 26(4), 641-668. https://doi.org/10.1002/jae.1133

Nasrullah, M., Sana, M., Bhutta, Z. A., \& Raj, A. (2014). Girl Child Marriage and Its Effect on Fertility in Pakistan: Findings from Pakistan Demographic and Health Survey, 2006-2007.

Oaxaca, R. (1973). Male-female wage differentials in urban labor markets. Int Econ Rev, 4(3), 693-709. https://doi.org/10.2307/2525981

Odwe, G. O (2015). Fertility and Household Poverty in Kenya: A Comparative Analysis of Coast and Western Provinces.

Palamuleni, M. E. (2014). Social and Economic factors affecting Ethnic Fertility differentials in Malawi. International Journal of Development and Sustainability, 3(1), 70-88.

Powers, D. A., Yoshioka, H., \& Yun, M. S. (2011). mvdcmp: multivariate decomposition for nonlinear response models. Stata J, 11(4), 556-76. https://doi.org/10.1177/1536867X1101100404

Sajeda, A., Diamond, I., Ruchira, T. N., \& Newby, M. (1998). Transition to Adulthood of Female Garment-factory Workers in Bangladesh. Studies in family planning, 29(2), 185-200.

Saranga, J., \& Kathleen, K. (2007). New Insights on Preventing Child Marriage. A Global Analysis of Factors and Programs.

Schockaert, I. (2005). Travail féminin et fécondité en Amérique latine. Un état de la question. Population, 60, 157-178. https://doi.org/10.3917/popu.501.0157

Schoumaker, B., \& Tabutin, D. (1999). Relationship between poverty and fertility in Southern countries: Knowledge, methodology and cases. Working Paper no 2. Department of Science of Population and Development, Université Catholique de Louvain.

Tabutin, D. (2003). La ville et l'urbanisation dans les théories du changements démographiques, in Eggericks T., Gourbin C., Schoumaker B., Vandeschrick C. et Vilquin É. (eds), Populations et défis urbains. Actes de la Chaire Quetelet 1999, Louvain-la-Neuve, Academia Bruylant/Harmattan, 17-50.

Talnan, E., \& Vimard, P. (2003). Structure familiale, conditions de vie des ménages et fécondité en Côte d'Ivoire. Journées scientifiques du réseau démographie de l'AUF. Familles au Nord, Familles au Sud, Marseille.

Talnan, E., \& Vimard, P. (2009). Fécondité et urbanisation en Côte d'Ivoire : existe-t-il une transition urbaine de la fécondité ? Villes du Sud: dynamiques, diversités et enjeux démographiques et sociaux, AUF; Archives Contemporaines, 41-58.

United Nations Population Division (2013). National Transfer Accounts Manual: Measuring and Analyzing the Generational Economy. New York: United Nations.

Upadhay, U. D., \& Karasek, D. (2010). Women's Empowerment and Achievement of Desired Fertility in Sub-Saharan Africa. Working Paper Series 80 (Demographic and Health Research, Calverton).

Van den Broeck, G., \& Maertens, M. (2015). Female Employment Reduces Fertility in Rural Senegal. PLoS ONE, 10(3), e0122086. https://doi.org/10.1371/journal.pone.0122086

Zan, L. M. (2016). Politiques de population et réduction de la fécondité au Burkina Faso: limites et perspectives. African Population Studies, 30(2).

Zheng et al. (2016). Socioeconomic status and fertility intentions among Chinese women with one child. Human Fertility. https://doi.org/10.3109/14647273.2016.1154988

\section{Copyrights}

Copyright for this article is retained by the author(s), with first publication rights granted to the journal.

This is an open-access article distributed under the terms and conditions of the Creative Commons Attribution license which permits unrestricted use, distribution, and reproduction in any medium, provided the original work is properly cited. 